\title{
Thomsen-Friedenreich Antigen
}

National Cancer Institute

\section{Source}

National Cancer Institute. Thomsen-Friedenreich Antigen. NCI Thesaurus. Code C2528.

A type 1 core O-glycan with potential immunotherapeutic property. Thomsen-

Friedenreich (TF) antigen, a galactose disaccharide, is normally O-linked to serine or threonine residue of mucins (MUC1), a transmembrane glycoprotein overexpressed on epithelial cell surface of a variety of tumor cells. The expression of this antigen is associated with tumor cell adhesion, tissue invasion and agg ressiveness. When administered in a vaccine formulation, TF antigen may stimulate a cytotoxic T cell response against tumors expressing TF epitope, which may result in a reduction in tumor size. 